\title{
Green Hybrid Energy for Office Building
}

\author{
Constantin Filote ${ }^{1}$, Raluca-Andreea Felseghi ${ }^{1, *}$, Filip Cârlea $^{2}$, Mihai Raţăă $^{1}$, Claudia Steluţa Martiş̧ ${ }^{3}$, Alexandru Lavric $^{1}$, \\ Daniel Fodorean ${ }^{3}$ and Maria Simona Răboacă ${ }^{4, *}$. \\ ${ }^{1}$ Faculty of Electrical Engineering and Computer Science, "Ştefan cel Mare" University of Suceava, 720229 Suceava, Romania; \\ ${ }^{2}$ National Institute for Economic Research "Costin C. Kiriţescu" - INCE, Romanian Academy, 050711 Bucharest, Romania; \\ ${ }^{3}$ Faculty of Electrical Engineering, Technical University of Cluj-Napoca, 400114 Cluj-Napoca, Romania; \\ ${ }^{4}$ National Research and Development Institute for Cryogenic and Isotopic Technologies-ICSI, 240050 Rm. Valcea, Romania.
}

\begin{abstract}
This contribution presents a comparative study of operating a green energy hybrid system to sustain the power production mix of an office building. For this purpose, two scenarios of a hydrogen storage system $\left(\mathrm{S}_{1}\right)$ and battery energy storage $\left(\mathrm{S}_{2}\right)$ to sustain solar and wind energy inlets were compared from a technical, environmental and financial perspectives. $S_{1}$ - hydrogen technology system was found to be more performing than $\mathrm{S}_{2}$ - battery technology in terms of energy efficiency, as well as $\mathrm{CO}_{2}$ emissions and initial costs
\end{abstract}

\section{Introduction}

Nowadays, building development and design are led by global sustainability goals. In order to take advantage of the opportunities offered by the global energy transition process, new directions of development and implementation of building power generation systems should be undertaken [1].

The use of local renewable energy sources (RES), on-site green electricity production, hybrid energy systems and the adoption of Distributed Energy Resources (DER) - source of decentralized, community [2] - generated energy, are current concerns, directions and trends in global energy policies.

The current global energy context has triggered unprecedented action by responsible energy and environmental stakeholders. In line with the principles of sustainable development, climate and environmental experts have almost unanimously said that the main cause of climate change was due to the accumulation of $\mathrm{CO} 2$ from the fossil fuel burning with a major negative impact on the ozone layer.

In order to correct the environmental imbalance, environmental and energy policies have been promoted to reduce greenhouse gas emissions by reducing consumption and integrating renewable energy sources into energy generation systems. [3]

The main goal of EU energy policies is to develop the process of energy regeneration, especially energy produced through the use of wind, solar, hydropower, geothermal or biomass energy potential.

The new framework agreed by the European Council sets the European Union's target of at least 27\% in terms of the share of energy from renewable sources consumed in the EU in 2030. For the EU, investment needs are estimated to be around one thousand billion euros between 2015-2030, only for the production of energy from renewable sources. [4]

Dependence on Romania's primary energy imports is $18-20 \%$ compared to some EU member states that import an average of $53 \%$ of energy demand. Romania's energy independence will remain for the next two decades, even with a consolidation trend (80-85\%). Also, from an energetic point of view, Romania is at an atypical situation for the Southeast European region, as the dependence on external energy suppliers is minimal (the $3^{\text {rd }}$ least EU dependent country).

The current geopolitical framework offers Romania the opportunity to develop the energy sector over the next 20 years in the context of regional and global economic paradigm shifts. [4]

Renewable sources (RES) contribute to mitigating climate change by reducing greenhouse emissions, achieving sustainable development, protecting the environment and improving the health of citizens, while also contributing significantly to increasing energy security with a high potential and availability at the level of Romania.

The procedures and processes of production, capture, storage or conversion of all types of alternative energies are undergoing improvement, the costs of investments in the RES infrastructure are decreasing and the technological efficiencies of the conversion processes are constantly improving, making renewable sources the energy to provide a growing share of the needs of the planetary scale. [5]

Optimistic forecasts estimate alternative energy production to account for more than $50 \%$ of the total energy market around 2050 [4], but this depends on finding possibilities for massive electricity storage.

Under the above outlined conditions, this work comes to present a green hybrid energy system that is

\footnotetext{
${ }^{\text {* }}$ Corresponding author: andreea.felseghi@gmail.com; simona.raboaca@icsi.ro.
} 
supposed to energetically support, an office building located in Ramnicu Valcea, Romania.

In order to ensure $100 \%$ green power supply to the office building, two energy storage scenarios on the operation of the hybrid system were created, namely in scenario $1\left(\mathrm{~S}_{1}\right)$ - energy storage is produced through hydrogen $\left(\mathrm{H}_{2}\right)$ and harnessed through the fuel cell (FC) to provide energy for the building and the second scenario $\left(\mathrm{S}_{2}\right)$ - energy storage is stored in lithium-ion batteries (B).

In this regard, the following situations have been configured, optimized and simulated in operation [6]:

$\mathbf{S}_{\mathbf{1}}-\mathbf{P V}+\mathbf{W T}+\mathbf{H}_{\mathbf{2}}$ : the hybrid system is composed of photovoltaic panels (PV), wind turbine (WT), inverter (I) and hydrogen production, storage and conversion technology - electrolyzer (Ely), hydrogen tank, fuel cell (FC). The hybrid energy system makes use of both solar and wind energies as renewable primary green sources. For power supply of the office building during the peak load period and weather fluctuation conditions, fuel cell works and employes hydrogen conversion into electricity (secondary source of energy). The hydrogen is produced on-site by the electrolyzer by harnessing the renewable available energy sources (solar and wind).

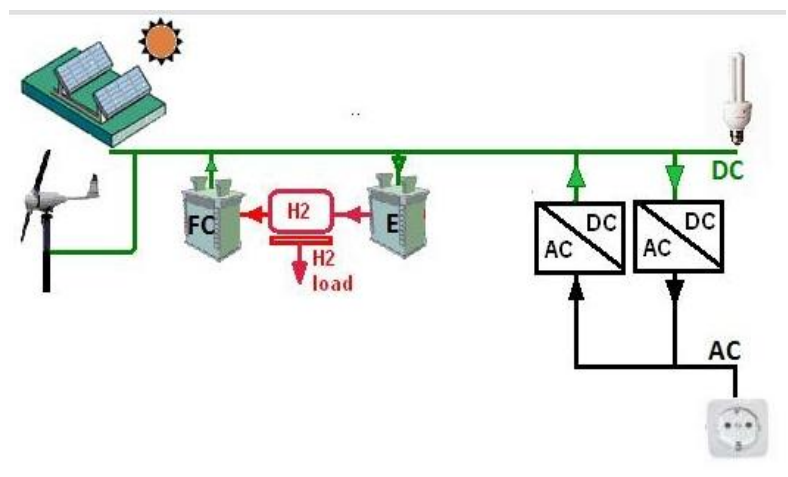

Fig. 1. $\mathrm{S}_{1}$ - schematic diagram [7]

$\mathbf{S}_{\mathbf{2}}-\mathbf{P V}+\mathbf{W T}+\mathbf{B}$ : in this scenario the hybrid system has the following main equipments: photovoltaic panels and a wind turbine for harnessing solar and wind resources, lithium-ion batteries for renewable energy storage and inverter for $\mathrm{DC} / \mathrm{AC}$ conversion.

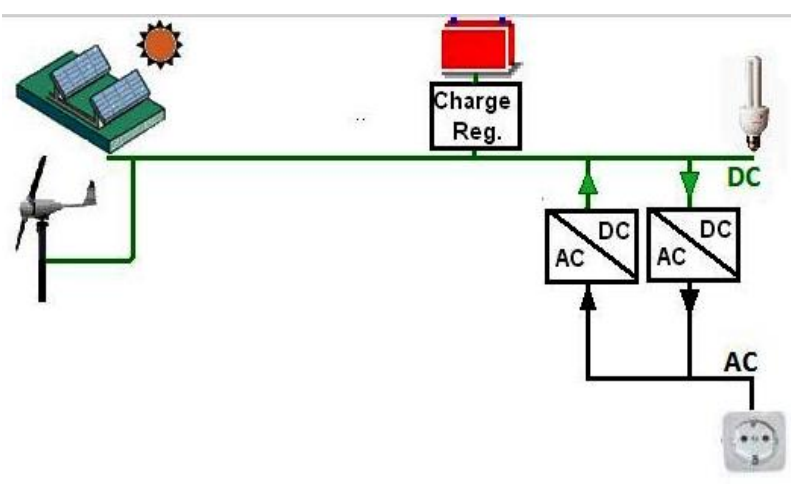

Fig. 2. $S_{2}$ - schematic diagram [7]

The purpose of this comparative analysis was to determine the optimal storage solution for the green hybrid system proposed for study, able to supply with electricity an office building.

\section{Input data}

In order for this comparative analysis to be feasible, it was necessary to define the input data regarding the load of the office building, the regional availability of green energy sources, the characteristics of the green energy hybrid system and the optimal system configuration. Also, it must be identified and specified the technical, environmental and cost characteristics of the main equipment. $[5,6,8,9]$

\subsection{Energy demand of the office building}

The average load profile is schematically represented in the figure 3.

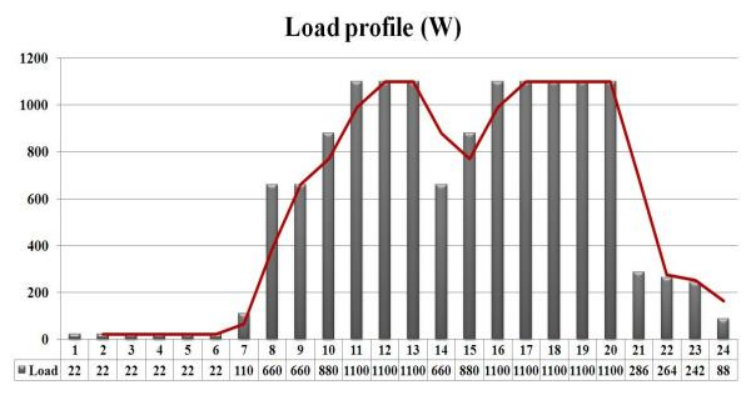

Fig. 3. Average hourly AC power

The energy demand of the office building that was examined for this research, registered an average daily load rate of $13.66 \mathrm{kWh} /$ day, an alternative current maximum hourly active power load of $1100 \mathrm{~W}$, an alternative current maximum in half hour intervals of $1268 \mathrm{~W}$ and average hourly alternative current power active of $569 \mathrm{~W}$.

\subsection{Solar and wind energy}

The studied office building where the green energy hybrid system is being implemented is placed in Ramnicu Valcea, Romania.

According to NASA Surface meteorology and Solar Energy: RETScreen Data [10], the location of climate data is as follows:

latitude $=45.10^{\circ} \mathrm{N}$,

longitude $=24.36^{\circ} \mathrm{E}$,

elevation $=545 \mathrm{~m}$,

frost days at site of 124 days,

cooling design temperature $=24.65^{\circ} \mathrm{C}$,

heating design temperature $=-10.00^{\circ} \mathrm{C}$,

earth temperature amplitude $=20.15^{\circ} \mathrm{C}$.

In Ramnicu Valcea, on the ground horizontal surface, the total annual solar irradiation is $1207.68 \mathrm{kWh} / \mathrm{m}^{2}$, the daily average solar irradiation is $3.30 \mathrm{kWh} / \mathrm{m}^{2}$.

On the PV tilt surface the total annual solar irradiation is $1285.96 \mathrm{kWh} / \mathrm{m}^{2}$, and the daily average solar irradiation is $3.52 \mathrm{kWh} / \mathrm{m}^{2}$ [10], as illustrated in figure 4. 


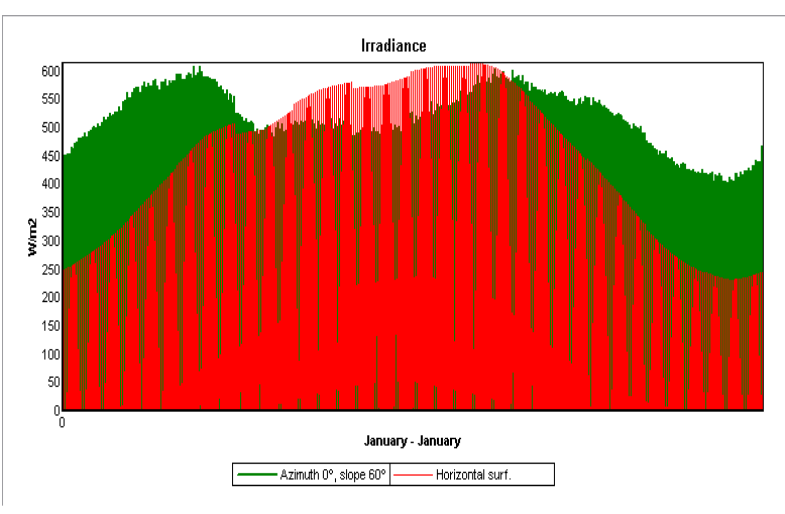

Fig. 4. Solar irradiation

For the studied site, the ground reflectivity is 0.2 , the azimuth of the photovoltaic panels is $0^{\circ}$ and the photovoltaic panels are not foreseen with sun tracking systems.

The values that will be taken into account for study represent the monthly average of wind speed registered at a distance of $10 \mathrm{~m}$ above the ground. The wind speed for Ramnicu Valcea can be observed in figure 5, which shows the graphic variation of annual average wind speed.

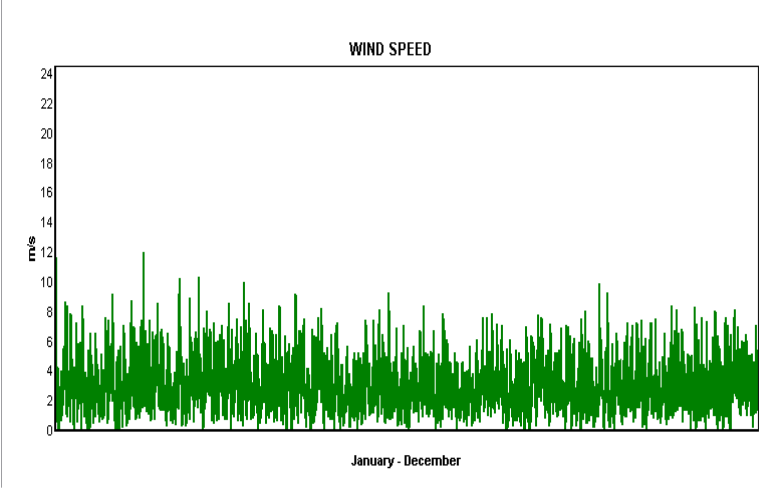

Fig. 5. Wind speed

In Ramnicu Valcea the scaled average wind speed is $3.02 \mathrm{~m} / \mathrm{s}$ [6], while taking into account for simulation in operation of wind turbines a correlation factor of 0.82 .

\subsection{Equipment components of hybrid systems}

The characteristics of the main equipment components of the green energy hybrid system [7] are as follows:

- PV: rated voltage $=24 \mathrm{~V}$, rated power $=280 \mathrm{Wp}$, shortcut current $=8.39 \mathrm{~A}, \mathrm{CO}_{2}$ emissions in manufacturing $=800 \mathrm{~kg} \mathrm{CO} \mathrm{CO}_{2}$ equiv. $/ \mathrm{kWp}$, acquisition cost $=350$ euro, Operations and Maintenance $(\mathrm{Q} \& \mathrm{M})$ cost $=3.5$ euro/year, expected lifespan $=25$ years;

- WT: output power (W) vs. wind speed $(\mathrm{m} / \mathrm{s})=$ $6345 \mathrm{~W}$ at $14 \mathrm{~m} / \mathrm{s}, \mathrm{CO}_{2}$ emissions in manufacturing $=3500 \mathrm{~kg} \mathrm{CO}$, acquisition cost $=12056$ euro, Q\&M cost = 225 euro/year, expected lifespan $=15$ years;
- $\mathrm{FC}$ : rated power $=1 \mathrm{~kW}, \mathrm{CO}_{2}$ emissions in manufacturing $=330 \mathrm{~kg} \mathrm{CO} 2$ equiv. $/ \mathrm{kW}$ rated power, acquisition cost $=7000$ euro, $\mathrm{Q} \& \mathrm{M}$ cost $=0.2$ euro/ hour of operation, expected lifespan $=40000$ hours;

- Ely: rated power $=2 \mathrm{~kW}, \mathrm{CO}_{2}$ emissions in manufacturing $=330 \mathrm{~kg} \mathrm{CO} 2$ equiv. $/ \mathrm{kW}$ rated power, acquisition cost $=13500$ euro, Q\&M cost $=1500$ euro/ year, expected lifespan $=20$ years;

- $\mathrm{H}_{2}$ tank: maximum capacity $=10 \mathrm{~kg}$, acquisition cost $=1000$ euro $/ \mathrm{kg}, \mathrm{Q} \& \mathrm{M}$ cost $=10$ euro $/$ year, expected lifespan $=25$ years;

- B: rated capacity $=23.5 \mathrm{Ah}$, rated voltage $=410 \mathrm{~V}$, $\mathrm{CO}_{2}$ emissions in manufacturing $=55 \mathrm{~kg} \mathrm{CO}$ equiv./kWh capacity, acquisition cost $=15200$ euro, Q\&M cost $=30$ euro/ year, expected lifespan $=45$ years;

- Inverter: power $=1600 \mathrm{VA}$, Imax_ch DC $=20 \mathrm{~A}$, acquisition cost $=1440$ euro, expected lifespan $=10$ years.

\section{Virtual simulation and optimization}

The energy, environmental and economic performances were calculated in accordance with the literature [5,11-15].

Computational optimization and simulations are achieved with improved Hybrid Optimization by Genetic Algorithms (iHOGA) software [7] and provide report regarding energetic, environmental and economical performances of the green energy hybrid system during one year of operation.

Multi-objectives optimization approach [7] was used and supplementary conditions were set in order to decrease the excess of energy, the total system cost and the $\mathrm{CO}_{2}$ emissions.

For the present comparative study the authors have adopted the Load following type of Control Strategy [7].

Two cases can be analysed when explaining the operating principle of the proposed system. If there is an excess of power generated from the PV and WT sources the electrolyser will produce hydrogen which will be stored for further consumption. In the case the energy generated from RES is not enough to supply the entire building the fuel cell will generate the required power using the already stored hydrogen $[12,15,16]$.

The second proposed scenario entails storing the energy excess in high capacity batteries, so that it can be used on demand if the RES generated power is less than the expected demand $[14,15]$.

\section{Results and discussion}

Based on the input data, it has been determined the optimum configuration of the green energy hybrid system in such a way as the overall load energy delivered to feed the office building was supplied $100 \%$ from RES in each of the two simulated assumptions. 
$\mathrm{S}_{1}$ is comprised of 2 series $* 15$ parallel photovoltaic panels (PV), 1wind turbine (WT), 1 inverter (I), 1 fuel cell (FC), 1 electrolyzer (Ely) $+1 \mathrm{H}_{2}$ tank, and $\mathrm{S}_{2}$ is comprised of 2 series $* 15$ parallel photovoltaic panels (PV), 1wind turbine (WT), 1 inverter (I), 4 lithium-ion batteries (B).

The results obtained under the provided conditions by the two scenarios are presented comparatively in the following subchapter. The comparative analysis was designed to determine the optimal storage solution for the Green Hybrid Energy System for Office Building.

\subsection{Energy performance}

The results of math calculations and virtual simulations are highlighted in figure 6 . For continuous use of the green energy hybrid system for 24 hours /day, during one year of operation, PV will produce an energy of $6473 \mathrm{kWh} /$ year, which represents $54.70 \%$ of the total energy generated by the system, while WT has produced an energy of $5359 \mathrm{kWh} /$ year, i.e. $45.30 \%$ of the total energy production.

Total green energy supplied by the hybrid system is $11832 \mathrm{kWh} /$ year during one year of operation. From the total generated hybrid energy, $42.14 \%$ is used for the office building.

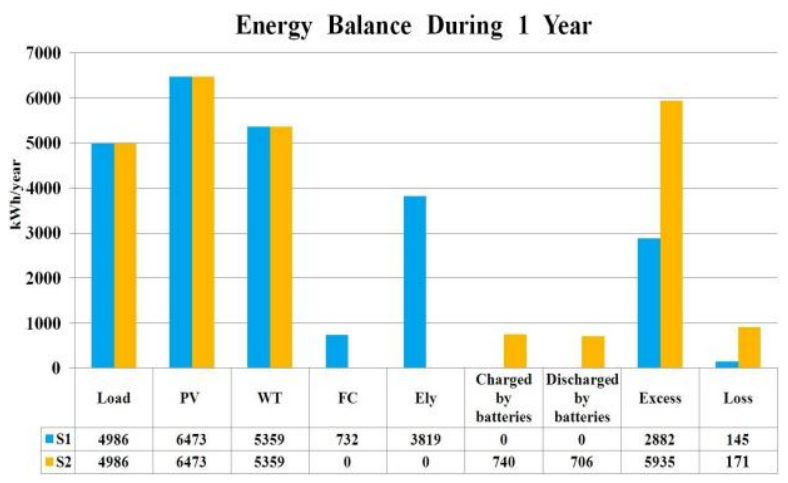

Fig. 6. $S_{1}$ - Energy balance for one year of operation

In $\mathrm{S}_{1}$ scenario, primary energy from renewable energy resources is harnessed through an electrolyzer in proportion of $32.28 \%(3819 \mathrm{kWh} / \mathrm{yr})$ of the total energy produced by the system, having a hydrogen production of 64.90 (kg/year) and operation time of 3058 (hours/year).

Fuel cell provides backup for the system, 6.20\% (732 $\mathrm{kWh} /$ year) of the office building's energy demand being covered by it.

From the operation of the hybrid system results an excess of energy of $24.35 \%$ (2882 $\mathrm{kWh} /$ year) of the total energy production, which can be used in applications, other than the power supply to the office building (i.e. "green-to-green" charging stations for electrical vehicles $[17,18])$.

Energy balance highlights the annual loss of energy of $1.23 \%$, due to the performance of the system components.

In $\mathrm{S}_{2}$ scenario, from the energy obtained by the hybrid system, $6.25 \%$ was stored into batteries to ensure backup, $50.16 \%(5935 \mathrm{kWh} /$ year $)$ was an excess of energy which can be used in other applications and the amount of $1.45 \%$ was lost due to the performance of the system components.

The monthly and annual average power are generated by the studied component equipment, the results obtained from the simulation of the two systems are illustrated graphically in figure $7\left(\mathrm{~S}_{1}\right)$ and figure $8\left(\mathrm{~S}_{2}\right)$.

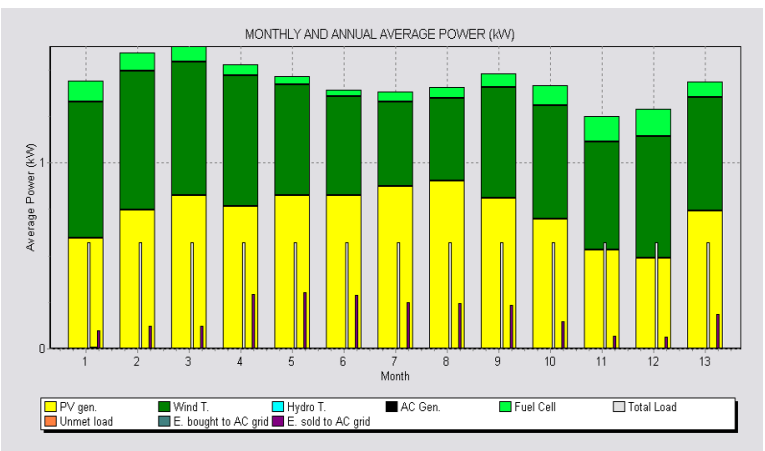

Fig. 7. $\mathrm{S}_{1}$ - Monthly and annual average power

Hybrid energy is the combined use of two or more forms of energy resulting in a more efficient energy system. Mainly, the advantage of combining the two types of primary energies (sun and wind) removes the deficiencies due to the intermittent availability of wind velocity, but also those of solar irradiation, especially the day/night alternation [19], and still keep the aspect regarding the uneven nature of energy generation.

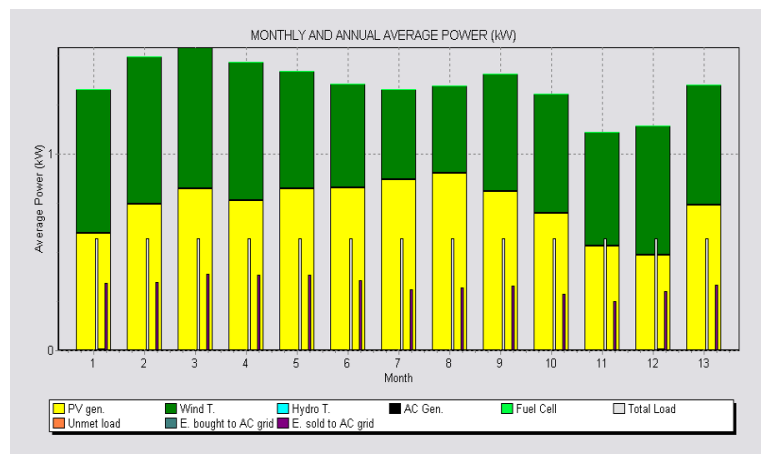

Fig. 8. $S_{2}$ - Monthly and annual average power

The worst-case scenario of the studied systems is recorder in December, when the energy demand of the office building is the maximum, and the value of the solar irradiation is minimal. The most favorable situation in which the studied systems work is registered in August, when the energy demand of the office building is minimal and the value of the solar irradiation is maximum. Wind power completes the energy mix so as to ensure the stand-alone building regime.

Exploiting surplus energy from primary sources of sun and wind through hydrogen in the $\mathrm{S}_{1}$ scenario has the advantage of long-term storage compared to simulated $\mathrm{S}_{2}$ battery storage which is dimensioned to provide system autonomy for 4 days.

The monthly hydrogen consumption and production, but also the amount of hydrogen stored in the hydrogen tank at the end of each month during a year are shown in figure 9 . 


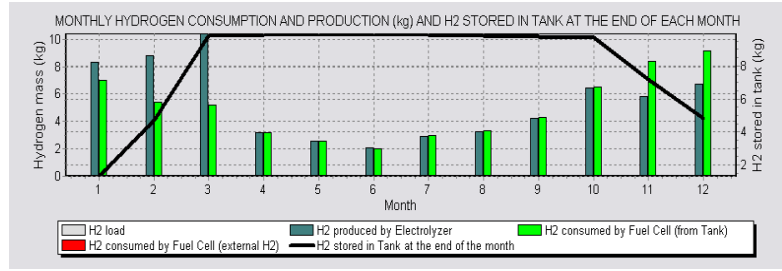

Fig. 9. $\mathrm{S}_{1}$ - Monthly hydrogen consumption and production

At the beginning of the simulated period (January March), hydrogen production is higher than hydrogen consumption, reaching the $10 \mathrm{~kg}$ capacity of the hydrogen tank by the end of March. Between April and October, hydrogen is produced electrolytically as much as it is needed, and between November and December consumption is higher.

Hydrogen consumption is conditioned by two factors: on one hand, the energy demand to be served by the fuel cell, and on the other hand, the availability of hydrogen fuel. It is important to stress that the hydrogen produced and stored in the hydrogen tanks is consumed according to the energy demand of the consumer, but there is also the case where a surplus of hydrogen can be obtained and further used for other applications. $[11,17,18,19]$.

In terms of energy performance, the hydrogen storage from scenario 1 is more efficient in harnessing renewable energy than the battery storage simulated in scenario 2 .

\subsection{Environmental performance}

The proposed green energy hybrid system generated $11832 \mathrm{kWh} /$ year with a total $\mathrm{CO}_{2}$ emission embedded in a system of $527 \mathrm{kgCO}_{2} /$ year in $\mathrm{S}_{1}$ and $591 \mathrm{kgCO}_{2} /$ year in $\mathrm{S}_{2}$. Generating electricity in classical mode $\left(\mathrm{S}_{\mathrm{C}}\right)$ by the National Energy System is accomplished with the release of $0.3055 \mathrm{kgCO}_{2} / \mathrm{kWh}$ [20]. To generate a quantity of electricity similar to that of the green energy hybrid system, $\mathrm{S}_{\mathrm{C}}$ would produce emissions in the amount of $3615 \mathrm{kgCO}_{2}$. The values are comparatively illustrated in figure 10.

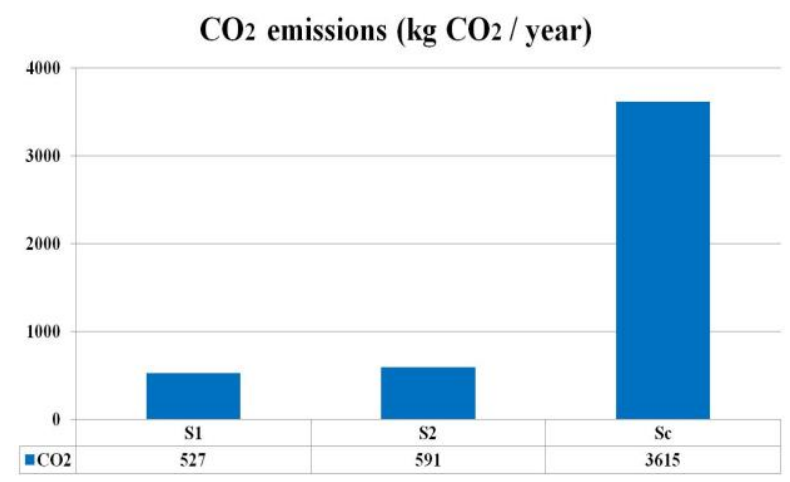

Fig. 10. $\mathrm{CO}_{2}$ emission

It is found that in $\mathrm{S}_{1}-\mathrm{CO}_{2}$ emissions are $85.42 \%$ lower than in the case of the classic electricity production system and in $\mathrm{S}_{2}-\mathrm{CO}_{2}$ emissions are $83.65 \%$ lower than in $\mathrm{S}_{\mathrm{C}}$.
Comparing the two scenarios of the case study, it is found that in case of $\mathrm{S}_{1}$ the $\mathrm{CO}_{2}$ emissions are lower by $18.83 \%$ compared to scenario $\mathrm{S}_{2}$. In terms of $\mathrm{CO}_{2}$ emissions, hydrogen storage from scenario 1 is friendlier with the environment than the battery storage system proposed in scenario 2 .

\subsection{Financial performance}

The initial investment cost comprises the equipment cost of the components included in the system. For the green energy hybrid system with storage based on the hydrogen technologies, the initial investment was calculated of 55886 euros $(€)$, and for the hybrid system with batteries as energy storage, the initial investment cost was of $87993(€)$.

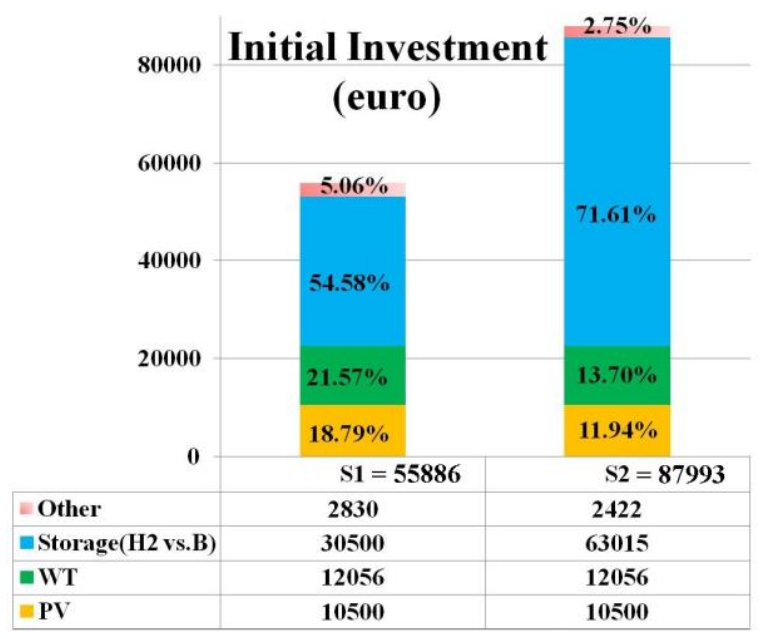

Fig. 11. Initial investment

It is found that the investment cost in $\mathrm{S}_{1}$ was $36.48 \%$ lower than in $\mathrm{S}_{2}$. As suggestively illustrated in figure 11, the energy storage medium through hydrogen is cheaper than lithium-ion battery storage.

\section{Conclusions}

Through comparative study the authors have created virtual conditions of operation of two hybrid systems capable to sustain with energy an office building. Then, the performances in operation of these systems have been determined with the purpose to prove the global capabilities of the systems and of the equipments. Next, it has been investigated the performances of the systems by comparing the possibilities and the solutions of RES storage, i.e. hydrogen technology and lithium-ion batteries.

The green energy hybrid system for office building analyzed in this paper can operate in stand-alone mode by using $100 \%$ renewable energy sources.

In terms of energy efficiency, hydrogen storage and technologies were more efficient in RES harnessing than lithium-ion batteries storage.

In terms of $\mathrm{CO}_{2}$ emissions, hydrogen technologies from $\mathrm{S}_{1}$ is more environment-friendly than lithium-ion battery storage discussed in $\mathrm{S}_{2}$. 
In terms of financial performances, hydrogen technology for storage and conversion into electricity by RES is more economically than lithium-ion battery storage variant, in terms of initial investment spending.

Developing the green building concept with the goal of increasing energy efficiency in the construction sector has brought important contributions to reducing the energy demand for buildings and greenhouse gas emissions, but the success of implementing this concept directly depends on the recovery solution of alternative energies through the various energy generation systems that will be adopted for the energy support of these constructions.

The next generation of green energy systems has significant potential for energy security and efficiency in the buildings sector, having a significant impact on reducing greenhouse gas emissions.

Acknowledgements: This work was supported by a grant from the Romanian Ministry of Research and Innovation, CCCDIUEFISCDI, project number PN-III-P1-1.2-PCCDI-20170776/No. 36 PCCDI/15.03.2018, within PNCDI III.

\section{References}

1. B. Mattoni,et al, Critical review and methodological approach to evaluate the differences among international green building rating tools, Renewable and Sustainable Energy Reviews 82, 1 (2018).

2. A.S. Hassan, L. Cipcigan, N. Jenkins, Impact of optimised distributed energy resources on local grid constraints, Energy 142, 1 (2018).

3. Renewable Energy Policy Network for the $21^{\text {st }}$ Century (REN21), Renewables 2017 Global Status Report, Paris, September 2017, ISBN 978-39818107-6-9.

4. Directive 2009/28/EC on the Promotion of the Use of Energy from Renewable Sources; European Parliament, Council of the European Union: Brussels, Belgium, 2009.

5. R.A. Felseghi, A. Papp, Considerations regarding hybrid systems of power generator from renewable energy sources, Studia Universitatis Babes-Bolyai, Ambientum 59 Issue 1/2 (2014), pp. 27-40.

6. G. Badea, R.A. Felseghi, et al, Comparative study regarding the global influence of energy storage medium on autonomous hybrid systems for a building with economical energy consumption, WSEAS Press, Kuala Lumpur, Malaysia, 24 (2014).

7. R. Dufo - López, J.L. Bernal - Augustin, iHOGA Software $\mathrm{PRO}+$, Electrical Engineering Department, University of Zaragoza, Spain, (2018).

8. D. Groppi, D. A. Garcia, G. L. Basso, F. Cumo, L. De Santoli, Analysing economic and environmental sustainability related to the use of battery and hydrogen energy storages for increasing the energy independence of small islands, Energy Conversion and Management (177),December 2018, pp. 64-76, doi.org/10.1016/j.enconman.2018.09.063.
9. Md Shahinur Islam, A techno-economic feasibility analysis of hybrid renewable energy supply options for a grid-connected large office building in southeastern part of France, Sustainable Cities and Society (38), April 2018, pp. 492-508, https://doi.org/10.1016/j.scs.2018.01.022.

10. NASA Surface meteorology and Solar Energy: RETScreen Data, accessed on May 6 (2018).

11. I. Aschilean, G. Rasoi, M.S. Raboaca, C. Filote, M. Culcer, Design and concept of an energy system based on renewable sources for greenhouse sustainable agriculture, Energies 11, 5 (2018).

12. M. Suresh, R. Meenakumari, An improved genetic algorithm-based optimal sizing of solar photovoltaic /wind turbine generator/diesel generator/battery connected hybrid energy systems for standalone applications, Int. Journal of Ambient Energy, (2019), doi:10.1080/01430750.2019.1587720.

13. R.D. Pentiuc, G. Baluta, C. Popa, G. Mahalu, Calculation of Reactances for Ring Windings to Toroidal Inductors of Hybrid Induction Machine, Advances in Electrical and Computer Engineering 9, 2 (2009), doi:10.4316/AECE.2009.02011.

14. R. Dufo - López, J.L. Bernal - Augustin, Multiobjective design of $P V$-wind-diesel-hydrogenbattery systems, J.Renewable Energy 33, (2008).

15. G. Badea, R.A. Felseghi, I. Aşchilean, A. Bolboacă, D. Mureşan, T.M. Şoimoşan, I. Ştefănescu, M.S. Răboacă, Energen System for Power Supply of Passive House. Case Study, $2^{\text {nd }}$ Int. Conference on Mathematics and Computers in Sciences and Industry, Malta, IEEE Explore (2016), doi: 10.1109/MCSI.2015.31.

16. S. Kharel, B. Shabani, Hydrogen as a long-term large-scale energy storage solution to support renewables, Energies 11, 10 (2018).

17. G. Badea, R.A. Felseghi, M. Varlam, C. Filote, M. Culcer, M. Iliescu, M.S. Raboaca, Design and Simulation of Romanian Solar Energy Charging Station for Electric Vehicles, Energies, 12 (1), 74, (2019), https://doi.org/10.3390/en12010074.

18. T.M. Şoimoşan, L.M. Moga, G. Danku, A. Căzilă, D.L. Manea, Assessing the Energy Performance of Solar Thermal Energy for Heat Production in Urban Areas: A Case Study, Energies, 12 (6), 1088, (2019), https://doi.org/10.3390/en12061088.

19. C. Marza, G.D. Corsiuc, A. Pop, Case study regarding the efficiency of electricity generation using photovoltaic panels, Proceeding of International Multidisciplinary Scientific GeoConference SGEM 2018, Section Renewable Energy Sources And Clean Technologies, doi:10.5593/sgem2018/4.1.

20. ANRE Annual Activity Report (2017). Available online: https://www.anre.ro/ro/despre-anre/rapoarteanuale (accessed on 27 December 2018). 